\title{
The Relationship Between Environmental Sanitation and Flies Density Rate in a Slaughterhouse in Sidoarjo Regency
}

\author{
Nailul Izzah Mahrusah ${ }^{1,}$ Supriyadi Supriyadii,** Agung Kurniawan ${ }^{3}$ \\ 1,3 Department of Public Health, Faculty of Sport Science, Universitas Negeri Malang, Malang, East Java, Indonesia \\ ${ }^{2}$ Department of Sport Science, Faculty of Sport Science, Universitas Negeri Malang, Malang, East Java, Indonesia \\ *Corresponding author. Email: supriyadi.fik@um.ac.id
}

\begin{abstract}
This study aimed to determine the relationship between fly density and environmental sanitation in Slaughterhouse. This research is quantitative research using a cross-sectional approach. Data analysis in this research was done using the ETA correlation test and showed a p-value of $<0.05$, which means that there is a significant relationship between the flies density and the behavior of waste management ( $p$ value $=0,000)$, there is a significant relationship between the flies density land the availability of waste disposal facilities ( $\mathrm{p}$ value $=0,000$ ), and there is a significant relationship between the flies density and SPAL conditions $(p$ value $=0,000$ ). A place with good environmental sanitation conditions will also have a good impact on public health
\end{abstract}

Keywords: flies density, slaughter house, enviromental sanitation

\section{INTRODUCTION}

The environment is one of the factors supporting the occurrence of disease. According to the World Health Organization (WHO), 24\% of the world's disease problems can be attributed to environmental problems [1]. Environmentally based diseases can be caused by poor environmental sanitation, such as improper waste treatment and the large number of uncontrolled disease vectors. One of the vectors that spread disease and coexist with humans is flies [2]. Flies can spread disease through their feet, wings, feathers, vomit, and feces. Flies will also excrete feces to lighten their bodies before flying [3]. Therefore, the device has the potential to spread environmental-based diseases such as diarrhea, cholera, typhoid dysentery and others [4].

The existence of flies closely related to the sanitary conditions in the place. Places with poor sanitary conditions can support rapid reproduction flies. Research conducted by Kartini in 2019 shortly get the result that the flies density are included in the high category is caused due to the condition of poor environmental sanitation, such as the bins are not eligible, the trash does not have a lid and holes and the waste allowed to accumulate for more than 3 days [5]. Flies also have the ability to transfer disease agents by contaminating the food they infest [6]. Today many processed foods with meat-based ingredients are liked by the public. The higher the public demand for meat, the higher the activities carried out at the Slaughterhouse [7].

Research on the condition of the Slaughterhouse was conducted by Subadyo in 2018 which explained that the method of separating and disposing of rumen contents at the Batu City still produces a lot of spillage. The contents of the rumen should be opened in a special place and then distributed to the rumen contents reservoir so that spillage can be minimized. This inappropriate thing causes an unpleasant odor and if not managed properly it will become a breeding medium for flies and mosquitoes [8]. Data from the Livestock Service Office of East Java Province in 2019, states that meat production in Sidoarjo Regency in 2018 has increased compared to the previous year, which was 7,522,583 $\mathrm{Kg}$, while in 2017 it was $6,833,840 \mathrm{Kg}$ [9]. With good sanitation conditions, it is hoped that the abattoir can produce meat that is decent and safe for public consumption. Therefore, it is necessary to conduct research on the relationship between environmental sanitation and the density of flies. The existence of this research is expected to help control vectors that cause disease, especially flies in the abattoir so that the meat produced is safe for public consumption. 


\section{METHOD}

This research is a type of quantitative research with a cross sectional approach, where data concerning the dependent variable and the independent variable will be collected simultaneously [10]. The analysis used to test the hypothesis is the eta correlation test which aims to determine whether there is a relationship between the independent variable and the dependent variable. The population of this research is the Slaughterhouse in Sidoarjo Regency, amounting to 2, namely Slaughterhouse A and Slaughterhouse B. This study uses a total sampling technique, namely the number of populations is the same as the number of samples due to the relatively small number of populations, so the entire population is used as a sample. sample. Data were collected using research instruments, including a fly grill to assist in measuring the density of flies, an interview guide containing a list of questions and an observation sheet containing a list of the conditions of the object under study.

\section{RESULTS AND DISCUSSION}

\subsection{Overview of Research Location}

Slaughterhouse A is the largest Slaughterhouse in Sidoarjo Regency which is managed directly by the Agriculture, Plantation and Livestock Service Office of Sidoarjo Regency. Slaughterhouse A has an area of about $15,800 \mathrm{~m}^{2}$ and slaughters $30-60$ head of cattle every day. Cutting activities are carried out starting at 20.00 WIB until finished and assisted by 30 workers or butchers. Slaughterhouse B is also a Slaughterhouse that is managed directly by the Agriculture, Plantation and Livestock Service Office of Sidoarjo Regency. Every day Slaughterhouse B slaughters 1-2 cows with 2 workers/butchers. The time for cutting activities starts at $00.00 \mathrm{WIB}$.

\subsection{Univariate Analysis}

The data analyzed were the number of fly density, waste handling behavior, the availability of waste disposal facilities and the condition of the waste water disposal channel. Data collection was carried out at 15 points in the Slaughterhouse Sidoarjo Regency, where 9 points were from Slaughterhouse A and 6 points from Slaughterhouse B.

Table 1. Number of Flies Density in Slaughterhouse A

\begin{tabular}{|l|l|l|}
\hline Flies Density Rate & Frequency & Percentage \\
\hline High & 0 & $0 \%$ \\
\hline Low & 9 & $100 \%$ \\
\hline Total & 9 & $100 \%$ \\
\hline
\end{tabular}

Based on the table above, it can be seen that from 9 points of measurement the density of flies in Slaughterhouse A obtained results in the high category of
$0 \%$ and the low category of $100 \%$. This shows that all research points in Slaughterhouse A have low fly densities.

Table 2. Number of Flies Density in Slaughterhouse B

\begin{tabular}{|l|l|l|}
\hline Flies Density Rate & Frequency & Percentage \\
\hline High & 0 & $0 \%$ \\
\hline Low & 6 & $100 \%$ \\
\hline Total & 6 & $100 \%$ \\
\hline
\end{tabular}

Based on the table above, it can be seen that from 6 points of measurement the density of flies in Slaughterhouse B got results in the high category of $0 \%$ and the low category of $100 \%$. This shows that all research points in Slaughterhouse B have low fly densities.

Table 3. Waste Handling Behavior in Slaughterhouse A

\begin{tabular}{|l|l|l|}
\hline Waste Handling Behavior & Frequency & Percentage \\
\hline Well & 5 & $56 \%$ \\
\hline Bad & 4 & $44 \%$ \\
\hline Total & 9 & $100 \%$ \\
\hline
\end{tabular}

Based on the table above, it can be seen that the behavior of handling waste is in the good category by $56 \%$ and in the bad category by $44 \%$. This shows that most of the waste handling behavior of RPH A in Sidoarjo Regency is in the good category.

Table 4. Waste Handling Behavior in Slaughterhouse B

\begin{tabular}{|l|l|l|}
\hline Waste Handling Behavior & Frequency & Percentage \\
\hline Well & 4 & $67 \%$ \\
\hline Bad & 2 & $33 \%$ \\
\hline Total & 6 & $100 \%$ \\
\hline
\end{tabular}

Based on the table above, it can be seen that the behavior of handling waste is in the good category by $67 \%$ and in the bad category by $33 \%$. This shows that most of the behavior in handling waste at Slaughterhouse B in Sidoarjo Regency is in the good category.

Table 5. Availability of Waste Disposal Facilities in Slaughterhouse A

\begin{tabular}{|l|l|l|}
\hline Waste Handling Behavior & Frequency & Percentage \\
\hline Fulfill the requirements & 8 & $89 \%$ \\
\hline $\begin{array}{l}\text { Does not meet the } \\
\text { requirements }\end{array}$ & 1 & $11 \%$ \\
\hline Total & 9 & $100 \%$ \\
\hline
\end{tabular}

Based on the table above, it can be seen that the availability of waste disposal facilities in the eligible category is $89 \%$ and in the non-qualified category it is $11 \%$. This shows that most of the availability of waste disposal facilities for Slaughterhouse A in Sidoarjo Regency is in the category of fulfilling the requirements. 
Table 6. Availability of Waste Disposal Facilities in Slaughterhouse B

\begin{tabular}{|l|l|l|}
\hline Waste Handling Behavior & Frequency & Percentage \\
\hline Fulfill the requirements & 6 & $100 \%$ \\
\hline $\begin{array}{l}\text { Does not meet the } \\
\text { requirements }\end{array}$ & 0 & $0 \%$ \\
\hline Total & 6 & $100 \%$ \\
\hline
\end{tabular}

Based on the table above, it can be seen that the availability of waste disposal facilities in the eligible category is $100 \%$ and in the non-qualified category is $0 \%$. This shows that the availability of waste disposal facilities for Slaughterhouse B in Sidoarjo Regency is in the category of fulfilling the requirements.

Table 7. A Wastewater Sewer Condition in Slaughterhouse A

\begin{tabular}{|l|l|l|}
\hline Waste Handling Behavior & Frequency & Percentage \\
\hline Fulfill the requirements & 5 & $56 \%$ \\
\hline $\begin{array}{l}\text { Does not meet the } \\
\text { requirements }\end{array}$ & 4 & $44 \%$ \\
\hline Total & 9 & $100 \%$ \\
\hline
\end{tabular}

Based on the table above, it can be seen that the condition of the sewerage in the category meets the requirements of $56 \%$ and in the category does not meet the requirements of $44 \%$. This shows that most of the conditions for the sewerage of the Slaughterhouse A waste water in Sidoarjo Regency are in the eligible category.

Table 8. Wastewater Sewer Condition in Slaughterhouse B

\begin{tabular}{|l|l|l|}
\hline Waste Handling Behavior & Frequency & Percentage \\
\hline Fulfill the requirements & 4 & $67 \%$ \\
\hline $\begin{array}{l}\text { Does not meet the } \\
\text { requirements }\end{array}$ & 2 & $33 \%$ \\
\hline Total & 6 & $100 \%$ \\
\hline
\end{tabular}

Based on the table above, it can be seen that the condition of the sewerage in the category meets the requirements of $67 \%$ and in the category does not meet the requirements of $33 \%$. This shows that most of the conditions for the sewerage of Slaughterhouse B in Sidoarjo Regency are in the eligible category.

\subsection{Bivariate Analysis}

\section{Relationship between Flies Density and Waste Handling Behavior}

Table 9. Relationship between Flies Density and Waste Handling Behavior

\begin{tabular}{|c|c|c|c|c|}
\hline $\mathrm{R}$ & $\mathrm{R} 2$ & F Statistics & F Table & $\mathrm{p}$ \\
\hline 0.928 & 0.861 & 80.649 & 4.667 & 0.000 \\
\hline
\end{tabular}

Based on the table above, it can be seen that the probability value $<0.05$ and $F$ statistic $>\mathrm{F}$ table which shows there is a significant relationship between the density of flies and the behavior of handling waste in the Slaughterhouse Sidoarjo Regency. The correlation coefficient value is 0.928 which indicates that there is a very strong relationship between the two variables. The magnitude of the contribution of the density of flies to the behavior of waste handling is 0.861 . The behavior of handling waste in the Slaughterhouse Sidoarjo Regency which is included in the good category can be seen from the habit of transporting waste $1 \times 24$ hours, maintaining the cleanliness of the Slaughterhouse area by cleaning the cage from leftover feed and dirt every day. This is in accordance with the Regulation of the Minister of Agriculture concerning Requirements for Ruminant Slaughterhouses.

The results showed that the low density of flies was influenced by good waste handling behavior. This is in accordance with research conducted by Putu Mutiara Ayu (2020) that there is a significant relationship between the level of knowledge, attitudes and actions of traders with the density number of flies obtained from statistical results using the chi square test, namely the $\mathrm{p}$ value of $0.000<(0.05)$ [11]. A similar study was conducted by Ihsan Murdani (2020) who found that restaurants with good sanitation measures had low fly density numbers. This is because the restaurant already has good waste management, provides hand washing and soap for customers, kitchen conditions that meet the requirements and good food processing [12].

Research that has been done shows that good behavior or actions will have a positive impact on environmental conditions. Waste management that is not optimal will cause discomfort in the environment and can invite disease vectors that can have an impact on public health [13].

\section{Relationship between Flies Density and Availability of Garbage Disposal Facilities}

Table 10. Relationship between Flies Density and Availability of Garbage Disposal Facilities

\begin{tabular}{|c|c|c|c|c|}
\hline $\mathrm{R}$ & $\mathrm{R} 2$ & F Statistics & F Table & $\mathrm{p}$ \\
\hline 0.681 & 0.464 & 11.243 & 4.667 & 0.000 \\
\hline
\end{tabular}

Based on the table above, it can be seen that the probability value $<0.05$ and $\mathrm{F}$ statistic $>\mathrm{F}$ table which shows that there is a significant relationship between the density of flies and the availability of waste disposal facilities in the Slaughterhouse Sidoarjo Regency. The correlation coefficient value is 0.681 which indicates that there is a strong relationship between the two variables. The contribution of the density of flies to the availability of waste disposal facilities is 0.464 . The waste disposal facilities at the Slaughterhouse Sidoarjo Regency which are included in the eligible category can be seen from the 
capacity of waste disposal according to the volume of waste generated, the availability of landfills in certain places, the conditions around the waste disposal do not cause odor and there is no scattered garbage and Trash cans must be closed, watertight and easy to clean. This is in accordance with the Regulation of the Minister of Agriculture concerning Requirements for Ruminant Slaughterhouses.

The results showed that the low fly density was influenced by the qualified waste disposal facilities. This is in line with research conducted by Ervian Wardaningrum (2019) that there is a significant relationship between waste disposal facilities and the density level of flies. From the statistical results using the fisher exact test, a p value of 0.038 was obtained with a risk calculation of $\mathrm{RP}=9.5$ which means that the condition of poor waste disposal facilities has a risk of 9.5 times resulting in a high density of flies than good waste disposal facilities [14] .

A similar study was conducted by Matadel Adane (2017) that the high density of flies is caused by poor sanitation facilities such as scattered garbage due to inadequate disposal facilities [15]. Garbage is closely related to health because in the waste live various microorganisms that cause disease and animals that cause disease [16] . The existence of good and qualified waste disposal facilities will create a clean and well-maintained environment. This condition can reduce vector and rodent breeding sites so as to reduce the potential for environmental-based disease transmission.

\section{Relationship between flies density and SPAL conditions}

Table 11. Relationship between flies density and SPAL conditions

\begin{tabular}{|c|c|c|c|c|}
\hline $\mathrm{R}$ & $\mathrm{R} 2$ & F Statistics & F Table & $\mathrm{p}$ \\
\hline 0.928 & 0.861 & 80.649 & 4.667 & 0.000 \\
\hline
\end{tabular}

Based on the table above, it can be seen that the probability value is $<0.05$ and $F$ statistic $>\mathrm{F}$ table which shows that there is a significant relationship between the number of fly density and SPAL conditions in the Slaughterhouse Sidoarjo Regency. The correlation coefficient value is 0.928 which indicates that there is a very strong relationship between the two variables. The magnitude of the contribution of the density of flies to the SPAL condition is 0.861 . The condition of the SPAL in the Slaughterhouse Sidoarjo Regency which is included in the eligible category can be seen from the drainage channel from the bathroom and toilet which is specially made towards the septic tank and is separated from the cutting process waste water disposal channel, the hole towards the waste water disposal channel is equipped with a filter and system. sewers are designed so as not to pollute the soil. This is in accordance with the Regulation of the Minister of Agriculture concerning Requirements for Ruminant Slaughterhouses.

The results showed that the low density of flies was influenced by the conditions of SPAL that met the requirements. This is in line with research conducted by Mutmainna Kasiono (2016) that there is a significant relationship between the condition of the sewerage and the density of flies. From the statistical results obtained $p$ value of $0.00<5 \%$ which indicates a relationship between the two variables. The presence of flies in a high category in a place is an indication of poor environmental sanitation [17].

A similar study conducted by Nartika Emelia Mongoli in 2016 showed the results of the density level of flies in the sewerage channel in the high category found in environmental sanitation that did not meet the requirements. In this study, sanitation that did not meet the requirements was one of the reasons for the sewerage that did not flow smoothly [18]. Another study conducted by Hafiz Azhar Ali Khan in 2013 found that the density of flies can be controlled effectively by reducing or eliminating the breeding sites of 1 tools [19]. Places with sewers that do not flow smoothly and cause unreasonable odors can become breeding grounds for vectors and rodents [20]. This can be a medium for the spread of various diseases and will have a negative impact on public health [21]

\section{CONCLUSION}

Based on the research that has been done, it can be concluded that there is a relationship between waste handling behavior and the density of flies, there is a relationship between the availability of garbage disposal facilities and the density of flies and there is a relationship between the condition of the sewerage and the density of flies in the Sidoarjo Slaughterhouse.

\section{AUTHORS' CONTRIBUTIONS}

NIM:concept and design the study, methodology, analysis, writing; S \& AK: validation, writing review, supervision

\section{ACKNOWLEDGMENTS}

The authors would like to thank Faculty of Sport Science, Universitas Negeri Malang for supporting this study.

\section{REFERENCES}

[1] Waste Atlas Partnership - D-Waste, ISWA, University of Leeds, WtERT SN and S. Waste Atlas. 2014; Available from: http://wedocs.unep.org/handle/20.500.11822/975 1 
[2] Wibowo AH. Survey of fly density (Diptera) in poultry market area and poultry slapping house, Semarang, 2015;8:1-4.

[3] Andini T, Siregar SD, Siagian M. The Effectiveness of Modified Fly Grill Technology to Reduce Flies Density at Meat Sales Places at Sukaramai Market, Medan City. J Health Glob. 2019;2(2):54.

[4] Sulistiowati A, Miftakhuddin, Wulandari. Flies in the Traditional Market in Tembalang District (Study in Mrican Market and Kedungmundu Market in Tembalang District). Thesis [Internet]. 2017;(25):8-22. Available from: http://repository.unimus.ac.id/992/3/BAB II Flies.pdf

[5] Kartini AA. Density and Methods of Control of Flies in the Grand Nusa Housing, Liliba Village, 2019. 2019;

[6] Andiarsa D. Flies: A Vector That Programs Neglect? Balaba J Research and Development on Disease Control from Animal Source Banjarnegara. 2018;201-14.

[7] Gaznur ZM, Nuraini H, Priyanto R, Postgraduate S, Animal Husbandry F. Evaluation of the Implementation of Sanitation and Hygiene Standards in Category II Slaughterhouses (Evaluation of sanitation and hygiene standard). 2017;18(36):107-15.

[8] Subadyo AT. Impact Management of Ruminant Slaughterhouse Construction in Batu City. J Servant of Masy Univ Merdeka Malang. 2018;2(2):15-20.

[9] Livestock Service Office of East Java Province. Production Statistics [Internet]. 2019. Available from:

http://disnak.jatimprov.go.id/web/data/datastatisti $\mathrm{k} /$ statistikhasil\#

[10] Notoatmodjo. Health Research Methodology. 2nd ed. Jakarta: Rinekacipta; 2012.

[11] Ayu PM. The Relationship between Knowledge Levels, Attitudes and Actions of Traders in Managing Waste with Density of Flies at the Sembung Traditional Village Market in 2020. 2020;10(2):108-15.

[12] Murdani I, Zakiyuddin, Duana JMMIFM. The Relationship of Hygine Sanitation, Sanitation Facilities and Exchanger Actions With Fly Density Levels in Dining House in Meulaboh City. 2014;45-51.

[13] Rarindo H, Husodo AH. The Relationship between Perceptions of Environmental Health and Clean Production Motivation with Waste Management Behavior in High School Students. Dr Diss Univ Gajah Mada. 2011;
[14] Wardaningrum E. Fly density level in SMAN Madiun. 2019.

[15] Adane M, Mengistie B, Kloos H, Medhin G, Mulat W. Sanitation facilities, hygienic conditions, and prevalence of acute diarrhea among underfive children in slums of Addis Ababa, Ethiopia: Baseline survey of a longitudinal study. PLOS One. 2017;12(8):1-18.

[16] Sari RE. Overview of School Canteen Hygiene and Sanitation (Comparative Study of Urban Junior High Schools and Rural Junior High Schools). 2013; Available from: http://repositori.uin-alauddin.ac.id/

[17] Kasiono AM, JM U, H B. Relationship between Basic Sanitation and Density Levels of Flies at Tumining Market Restaurant, Manado City. 2016;

[18] Mangoli NE, Pinontoan OR, Boky H, Health F, University $\mathrm{M}$, Ratulangi S, et al. Relationship basic sanitation with fly density levelin the Pinasungkulan Karrombasan Restaurant, Manado in 2016. 2016;19.

[19] Khan HAA, Akram W, Shad SA, Razaq M, Naeem-Ullah U, Zia K. A cross sectional survey of knowledge, attitude and practices related to house flies among dairy farmers in Punjab, Pakistan. J Ethnobiol Ethnomed. 2013;9(1):1-10.

[20] Andriana A. The Relationship between Basic Sanitation and the Density Level of Flies in the Pasar Besar Restaurant, Madiun City. Public Health Study Program Thesis [Internet]. 2019;179. Available from: http://repository.stikesbhm.ac.id/ [Accessed on April 3, 2021]

[21] LS Sky. The Relationship between Basic House Sanitation Conditions and the Incidence of Diarrhea in Toddlers in the Work Area of the Rembang Health Center 2. 2016;4(April):160-5. 